\title{
Flower and ornamental plants wholesale markets in Brazil (1)
}

\author{
LUCAS CARVALHO E SILVA', PATRÍCIA DUARTE \\ DE OLIVEIRA PAIVA ${ }^{* 2}$, ANTÔNIO CARLOS SANTOS ${ }^{3}$
}

\begin{abstract}
RESUMO
In Brazil, formal wholesale trade of floriculture products is concentrated in the state of São Paulo, which represents $90 \%$ of the national market. Through the most diverse sales systems, wholesale trade of flowers and ornamental plants is in expansion and is carried out both in supply centers and sales centers. The aim of this study is to present the characteristics, dynamics, and history of trade in the main flower and ornamental plant wholesale markets in Brazil. To analyze these markets, we collected primary data provided by the wholesale markets themselves and secondary data obtained from bibliographic research. The wholesale flower and ornamental plant market in Brazil is concentrated in the state of São Paulo, although there are supply centers in other states. This market is mainly formed by Veiling Holambra, CEASA/Campinas, CEAGESP-ETSP, and Cooperflora/Floranet, with transactions of more than R $\$ 732$ million/year, and $48.77 \%$ of this amount is through Veiling Holambra.
\end{abstract}

Keywords: flower trade, Veiling Holambra, Ceasa Campinas, Cooperflora and Floranet

\begin{abstract}
Mercado atacadista de flores e plantas ornamentais do Brasil

No Brasil, a comercialização formal dos produtos da floricultura, em atacado, concentra-se no estado de São Paulo, que representa $90 \%$ do mercado nacional. Por meio dos mais diversos sistemas de comercialização, e realizado tanto em centrais de abastecimento quanto em centros de comercialização, o comércio atacadista de flores e plantas ornamentais encontrase em expansão. O objetivo desse trabalho é apresentar as características, dinâmicas e o histórico da comercialização nos principais mercados atacadistas de flores e plantas ornamentais do Brasil. Para analisar esses mercados, foram levantados dados primários, fornecidos pelos próprios mercados de comércio atacadista, e secundários, obtidos a partir de pesquisas bibliográficas. O mercado atacadista de flores e plantas ornamentais no Brasil se concentra no estado de São Paulo, apesar da existência de centrais em outros estados. Esse mercado é formado, principalmente, pelos mercados da Veiling Holambra, CEASA/Campinas, CEAGESP-ETSP e Cooperflora/Floranet, os quais movimentam mais de R 732 milhões/ano, sendo que $48,77 \%$ desse valor é realizada pela Veiling Holambra.
\end{abstract}

Palavras-chave: comercialização de flores, Veiling Holambra, Ceasa Campinas, Cooperflora e Floranet.

\section{INTRODUCTION}

In Brazil, formal wholesale trade of floriculture products is concentrated in the state of São Paulo, representing $90 \%$ of the Brazilian market. These transactions mainly occur at the Cooperativa Veiling Holambra (Veiling Holambra) [Veiling Holambra Cooperative], at the Mercado Permanente de Flores e Plantas Ornamentais [Permanent Flower and Ornamental Plant Market] of CEASA/Campinas (CEASA/Campinas), at the Entreposto Terminal São Paulo [São Paulo Terminal Trading Center] ETSP (CEAGESP-ETSP), and at the Cooperflora/Floranet (JUNQUEIRA and PEETZ, 2008).

The wholesalers of these markets provide extensive services to the supply chain of flowers and ornamental plants. These services may be classified in two groups: 1) factors connected with demand: greater ease of access to the goods, both for the final consumer and for the dealer, and adjustment of discrepancy of assortment (adjustment between the variety of goods supplied and demanded) and; 2) factors connected with supply: reduction of transaction and contract costs (COUGHLAN et al., 2002).

Auction or Klok is the trading system adopted by Veiling Holambra. This system is known for the speed with which transactions occur. The auction occurs in reverse, i.e., it begins with the maximum price, which decreases as time passes, until the buyer picks up the goods.

According to JUNQUEIRA and PEETZ (2008), Veiling Holambra represents $30 \%$ of the total of flowers and ornamental plants (FOP) traded in Brazil. Trading in this system offers the possibility to the producer of participating in a strong and representative group in the Brazilian market

\footnotetext{
(1) Trabalho recebido para publicação em 19/09/2013 e aprovado em 29/07/2014

(2) Grupo Agrihold/ALTA-América Latina Tecnologia Agrícola. Patrocínio-MG. Brazil.

(3) Department of Agriculture/DAG, Universidade Federal de Lavras/UFLA, 37200-000 - Lavras, MG, Brazil. *Autor correspondente patriciapaiva@

dag.ufla.br

(4) Departament of Administration and Economics/DAE, Universidade Federal de Lavras/UFLA, 37200-000 - Lavras, MG, Brazil.
} 
and also drastically reduces default in the transactions. The supply of a broad mix of products, transparency in sales information, and infrastructure adequate for purchases, payments, loading, and storage are the advantages for those who choose to buy in the auction of Veiling Holambra (VEILING HOLAMBRA, 2011).

The Cooperativa dos Floricultores (Cooperflora) [Floriculture Cooperative] was created in 1999 by floriculturists in the region of Holambra, SP. This cooperative is a specialized supplier in the cut flower segment, which in 2011 was made up of 48 producers, located in 5 Brazilian states (COOPERFLORA ${ }^{4}$ ).

Floranet, a private company with main offices in the municipality of Holambra, SP, was created in November 1998 by a group of professionals with recognized experience in floriculture and also uses an electronic trading system (call center) (FLORANET, 2012). Although they are not legally connected, Floranet operates as a sales representative of Cooperflora.

CEASA/Campinas has the largest permanent FOP market in Latin America. Inaugurated in 1995, it transacts around 4 thousand tons of products/month, coming from 68 municipalities of various regions in Brazil. The complex has around 28.6 thousand $\mathrm{m}^{2}$ of covered area, 504 points of sale (booths), 8 deposits, and cold storage. The market makes more than 20 thousand FOP items available and another 5 thousand accessory products for decoration and finishing of arrangements, baskets, and landscaping (CEASA CAMPINAS, 2012).

This market is characterized by proximity to the areas of production; $60 \%$ of total FOP production of São Paulo is found in a $60 \mathrm{~km}$ radius of it. In all, there are 17 municipalities, and six of them are among the top 10 in the state (TSUBOI and TSURUSHIMA, 2009). In addition to location, the consolidation of this market, which is managed by the municipality of Campinas, is due to the market standards created and inspected by market administration. Among the main regulations, registration of customers/clients and specific schedules for loading and unloading goods stand out. The CEASA/Campinas market is among the three largest in FOP trade in Brazil (CEASA CAMPINAS $^{5}$ ).

The fact that there is a different schedule for wholesale (registered customers) and retail (non-registered customers) assists trade logistics in CEASA/Campinas since it facilitates movement of people and goods within the market. That way, the time for the wholesaler to purchase goods and load the vehicle is optimized.

The Centro Estadual de Abastecimento (CEASA of São Paulo) [São Paulo Supply Center] was created in 1966. However, FOP trade only began after 1969 through expansion and reorganization of the system, which is currently called the Companhia de Entrepostos e Armazéns Gerais de São Paulo - CEAGESP [São Paulo General Trading Center and Warehouse Company] (TSUBOI and TSURUSHIMA, 2009).
The CEAGESP is made up of a network of 13 trading centers: the Entreposto Terminal de São Paulo - ETSP (CEAGESP-ETSP), and 12 more regional trading centers (CEAGESP, 2012).

In spite of its history and large Brazilian and international profile, the CEAGESP is a system with many bottlenecks, which compromise the dynamics of its operation. According to CASTRO (1998), this is due to the lack of supervision of the amounts traded, the lack of classification standards, the inadequate security of the trading center facilities, and the long trading periods.

Due to the fragility of the FOP and poor logistics between the locations of production and final consumption, the products traded in CEAGESP-ETSP pass through various loading/unloading operations. As a consequence, physical loss in this center is estimated to be at least $30 \%$ (ARNALDI, 2006).

Information in regard to trade and operation of wholesale FOP markets in Brazil is scarce and scattered. Thus the aim of this study was to present the characteristics, dynamics and history of trade in the main wholesale FOP markets in Brazil.

\section{MATERIALS AND METHODS}

For diagnosis of FOP trade in the main wholesale markets in Brazil, secondary data were obtained from bibliographical research and information provided by the wholesale trade markets themselves.

This information was sent by managers and those responsible for the markets of Veiling Holambra, Cooperflora/ Floranet, CEASA/Campinas, and CEAGESP-ETSP. It is important to highlight that making this market information available from the trading centers (Veiling Holambra, Cooperflora/Floranet, all private institutions) was only possible as a result of a mutual cooperation agreement signed between these institutions, represented by the Instituto Brasileiro de Floricultura - IBRAFLOR (Brazilian Floriculture Institute), and the Universidade Federal de Lavras - UFLA.

\section{RESULTS AND DISCUSSION}

In Brazil, the main wholesale flower and ornamental plant markets are Veiling Holambra, Cooperflora, CEASA/ Campinas, and CEAGESP-ETSP, all located in the state of São Paulo, with their own operational features.

\section{Veiling Holambra}

The Veiling Holambra market is located in the city of Santo Antônio de Posse, SP. This market has a differentiated sales system, carried out through daily auctions, which occur simultaneously on three "clocks" (Figure 1). On one clock, potted flowers and ornamental plants are traded; on another, cut flowers; and a third, located between the two other clocks, acts as a "wild card", operating with both cut flowers and potted flowers and ornamental plants, depending on the volume of goods to be traded that day.

\footnotetext{
${ }^{4}$ COOPERFLORA. (Cooperativa dos Floricultores - Cooperflora). Personal communication, 2012

${ }^{5}$ CEASA CAMPINAS (CEASA/Campinas). Personal communication, 2011.
} 


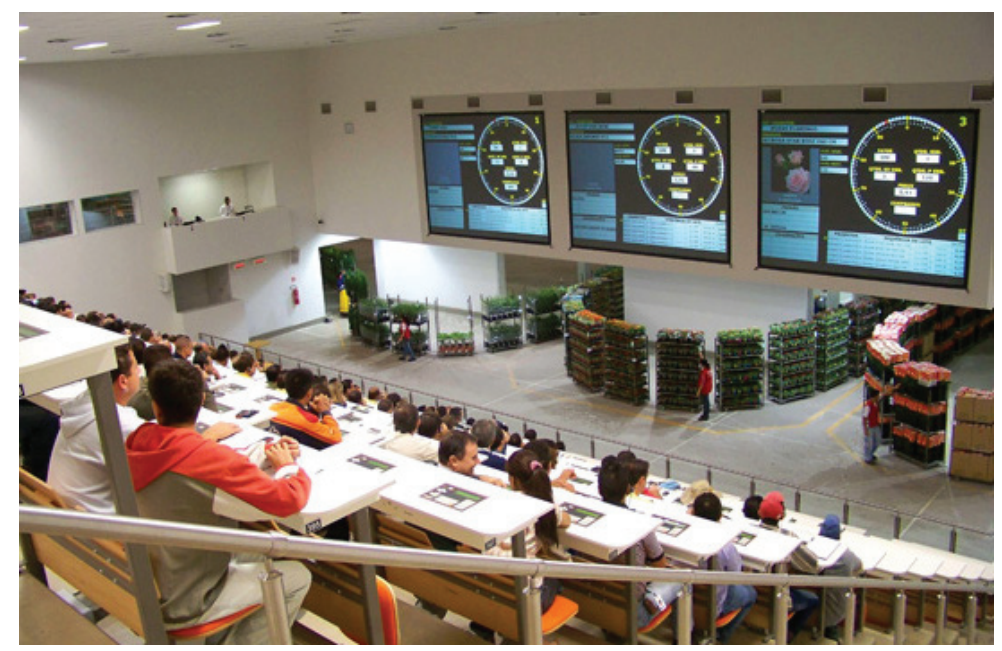

Figure 1. Flower and ornamental plant auction at the Cooperativa Veiling Holambra (2011)

Under the current system, a lot is acquired on average every 1.8 seconds. This efficiency in carrying out transactions allows a large volume of goods to be traded in a short period of time, which contributes to maintaining the quality of the FOP. Trading through auction represents $55 \%$ of the transactions of this market (VIZZOTO, 2011).

According to CASTRO (1998), buyers authorized to purchase at Veiling Holambra are: a) wholesale route distributors - these are wholesalers that cover routes from point to point throughout the country; b) forwarding agents - they purchase goods upon customer order and transport these goods to the customer; c) commission buyers or brokers - they receive a percentage relative to the value of the purchases made for third parties; d) cash and carry or self-service - this consists of large supermarket chains; and e) final customers: retailers and service providers.

However, not all the goods are traded through auction. In 1993, an intermediary sales system was introduced, i.e., the buyer makes contact with the seller (the sales department of Veiling Holambra) through telephone or Internet and makes the purchase. This process represents $45 \%$ of the turnover of Veiling Holambra. Most of the ornamental plants for landscaping and gardening are traded through this intermediary system (VIZZOTO, 2011).

So that transactions occur quickly and accurately, there needs to be standardization and classification of the goods. They are classified under the standards A1= goods of superior quality; A2 = goods of intermediate quality; and $\mathrm{B}=$ goods outside of standards and of lower quality (VELING HOLAMBRA ${ }^{6}$ ).

The goods arrive at Veiling Holambra in the end of the afternoon prior to their sale. This time is necessary for the logistics team to be able to organize the goods and identify all the carts (metallic structures that hold the FOP) in an adequate way. Before sending the goods to Veiling Holambra, through a designated system, the suppliers (producers) are to send information in regard to quality (according to the aforementioned classification) and quantity of the products that will be sent to Veiling Holambra (VEILING HOLAMBRA ${ }^{6}$ ).

The goods that are not sold at auction are destroyed and transformed into compost. The cost of this disposal is borne by the producers themselves (members of the cooperative of Veiling Holambra). The elimination of excess goods is a price protective mechanism. As production is constant, accumulation of goods on one day would consequently raise the supply on the following day, with a negative impact on price formation (VEILING HOLAMBRA ${ }^{6}$ ).

Figure 2 presents the supply chain of Veiling Holambra, summarizing all the relations of the cooperative with its suppliers and customers, as well as exhibiting the sales channels and services provided.

Although the supply chain of Veiling Holambra (Figure 2) appears to be a simple structure at first sight, it actually shows a complex and efficient system, functioning as a link between Cooperativa member producers, who are the suppliers, and the buyers.

The services provided by Veiling Holambra include quality control, logistics, and financial organization. In regard to transportation services ( $\mathrm{T} 1$ and $\mathrm{T} 2$ ), the Cooperativa does not have any responsibility over them. Transport of products to the Cooperativa (T1) is the responsibility of the producers, and transport from the Cooperativa to the final destination of the goods (T2), of the customer (VIZZOTO, 2011).

From the beginning of sale through auction, the transactions of Veiling Holambra show a trajectory of increasing growth. In 1989, it registered total annual sales of $\mathrm{R} \$ 12$ million and in 2011, R\$ 357 million - a growth of nearly $2,875 \%$ (Figure 3 ). 


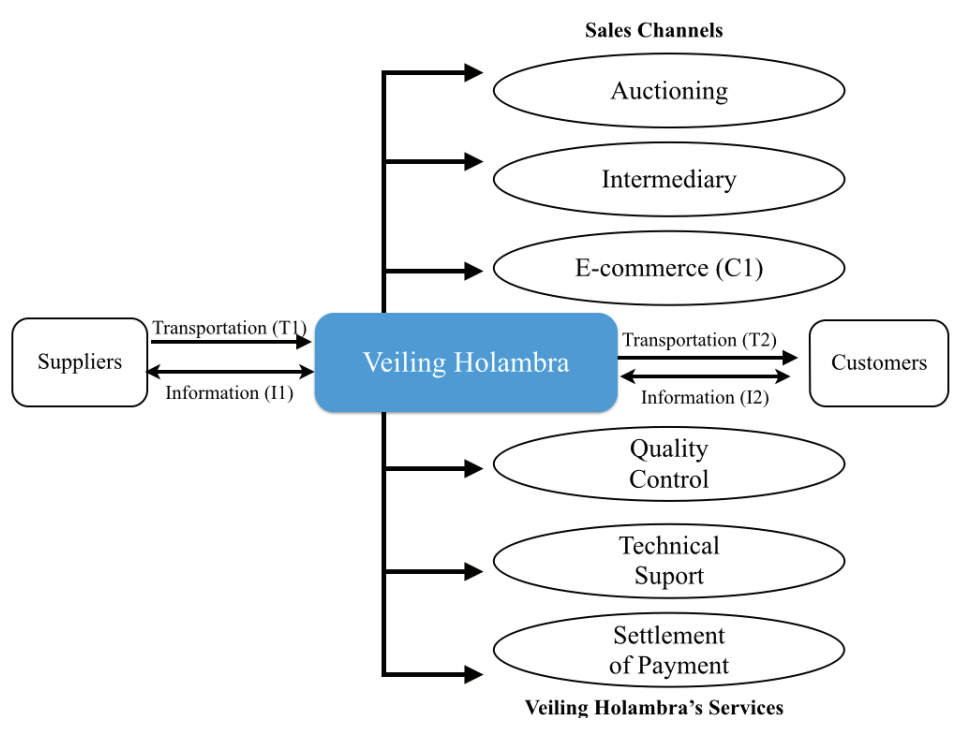

Figure 2. Supply Chain of the Cooperativa Veiling Holambra. Adapted from Vizzoto (2011)

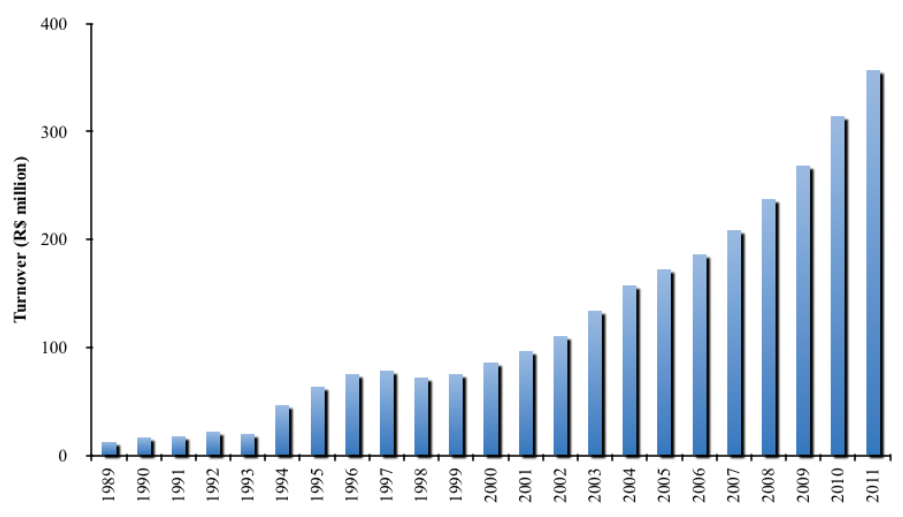

Figure 3. Total sales of the Cooperativa Veiling Holambra (1989-2011)

Veiling Holambra was inaugurated in July 2001. Before that, trading of FOP was carried out by the Cooperativa Agropecuária de Holambra (Holambra Crop and Livestock Cooperative) under the responsibility of its Flower Department. Since then, mean growth in its annual sales has been near 14\% (Figure 3).

The customer portfolio of Veiling Holambra is classified as: Route Distributors (wholesale route distributors), Garden Centers, CEASAs (wholesalers that have booths in the CEASAs), Floriculture Shops, Decorators, and Self-Service (supermarket chains). Figure 4 shows the share of each one of these segments in sales made by the cooperative in the period from 2003 to 2011 


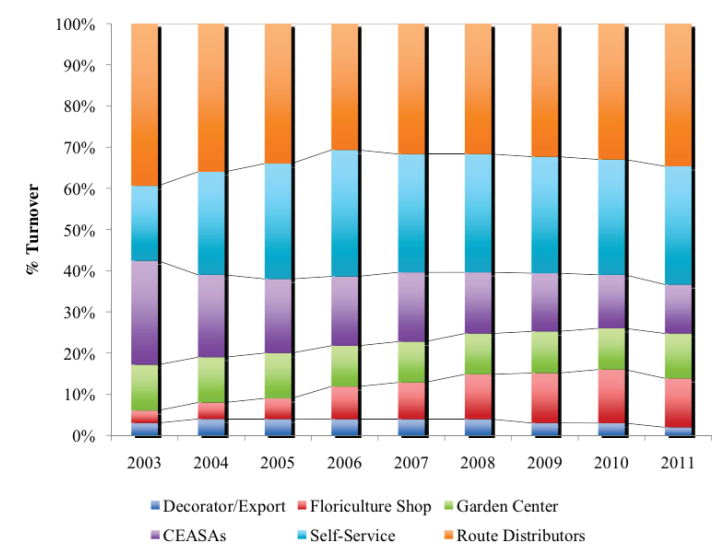

Figure 4. Customer share, per segment, in the total sales of the Cooperativa Veiling Holambra

Analysis of Figure 4 indicates the expansion of some segments, such as Floriculture Shops and Self-Service, and a reduction in others, such as Route Distributors and the CEASAs. In 2003, the segments with greatest expression in total sales of the cooperative were the CEASAs (25\%) and the Route Distributors (39\%). Analysis of the behavior of the segments in 2011 show that the Route Distributors are still of great importance in the total sales of Veiling Holambra, representing 35\%. In contrast, the CEASAs showed reduction in their share from $52 \%$ to only $12 \%$ of total sales in 2011.

Among the segments that showed positive growth, floriculture shops stand out, with an increase of $400 \%$ in the period from 2003 to 2011 (Figure 4). The expansion of the Self-Service segment confirms the increase of FOP within supermarket chains. The increase of this segment in total sales of Veiling Holambra from 2003 to 2011 was $61 \%$ (Figure 4).

\section{Cooperflora and Floranet}

The other important supplier, located in the municipality of Holambra, is Cooperflora. This cooperative is different from Veiling Holambra as it does not directly trade the products of its members. For that purpose it uses the services of another company, Floranet.

The relationships of Cooperflora and Floranet with its suppliers and customers, as well as the services provided by both, are shown in Figure 5 .

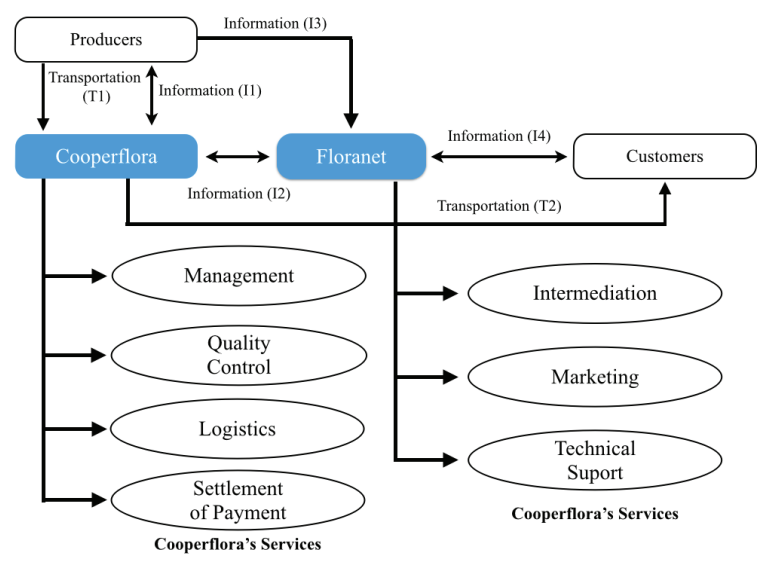

Figure 5. Supply Chain of Cooperflora/Floranet. Vizzoto (2011)

Cooperflora is responsible for management, quality control, logistics, and settlement of payments; and Floranet for intermediation between Cooperflora and its customers. In addition to intermediation, Floranet performs services related to marketing and technical support to customers (VIZZOTO, 2011).

Cooperflora, just as Veiling Holambra, does not have any responsibility for transport of goods from producers to the cooperative, or from the cooperative to the facilities of its customers.

According to Vizzoto (2011), information in the FOP sector is an important support mechanism for decisionmaking and for forecasting future market behavior. In relation to information flow, the importance of Floranet in the chain may be noted as an agent for connecting Cooperflora, suppliers, and customers (I2, I3, and I4, 
respectively). The information between suppliers and Cooperflora (I1) is provided through its own digital system in which the producer indicates the varieties, amounts, and quality of the products to be sold, which come to be part of the database. Floranet obtains customer demand (I4) and passes it on to Cooperflora (I2) and to the suppliers (I3) for meeting orders.

Just as Veiling Holambra, Cooperflora/Floranet is in expansion. In the three-year period 2009-2011, a mean annual increase of $13.6 \%$ was registered in sales of cut flowers, which represent more than $99 \%$ of the total sales of Cooperflora/Floranet (Figure 6).

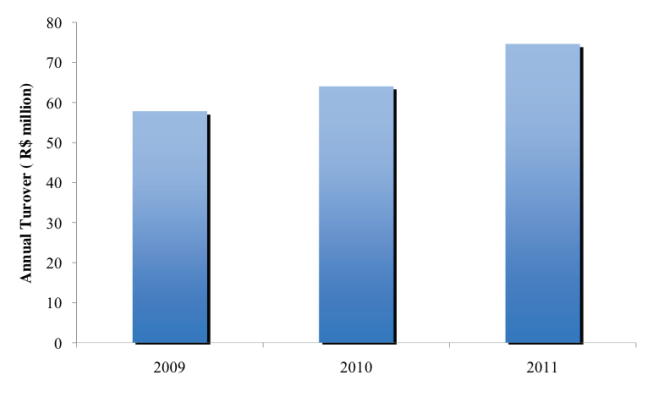

Figure 6. Annual sales of cut flowers of the Cooperativa dos Floricultores - Cooperflora (2009-2011).

Potted flowers and ornamental plants complete the list of products offered by the cooperative. Nevertheless, according to Figure 7, it may be seen that the share of these products has decreased $(66 \%$ in the three-year period 2009-2011), signaling the focus on cut flowers by the cooperative.

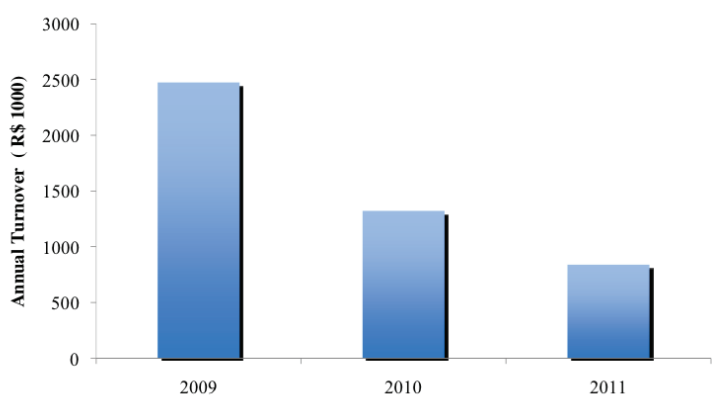

Figure 7. Total sales of the Cooperativa dos Floricultores - Cooperflora in relation to sales of potted flowers and ornamental plants (2009-2011).

\section{CEASA/Campinas}

Unlike the private trade centers (Veiling Holambra and Cooperflora/Floranet), statistical data in relation to sales of FOP in the public supply centers under public administration or governmental agencies (CEASA/ Campinas and CEAGESP-ETSP) do not reflect the real volumes transacted by the markets since they are indicated by the wholesalers themselves through manifests supplied when the goods enter the center. However, these numbers are presented because they constitute the only source of data that is officially available on the trade in the supply centers.

There has been increasing growth of the CEASA/ Campinas market since its opening. In 1999, excluding the sales of accessories (floral foams, plant pots, ribbons, etc.), the market had a turnover of around $\mathrm{R} \$ 54,689$ million, whereas in 2008, an increase of more than $90 \%$ was observed, passing to R\$104,703 million (Figure 8). 


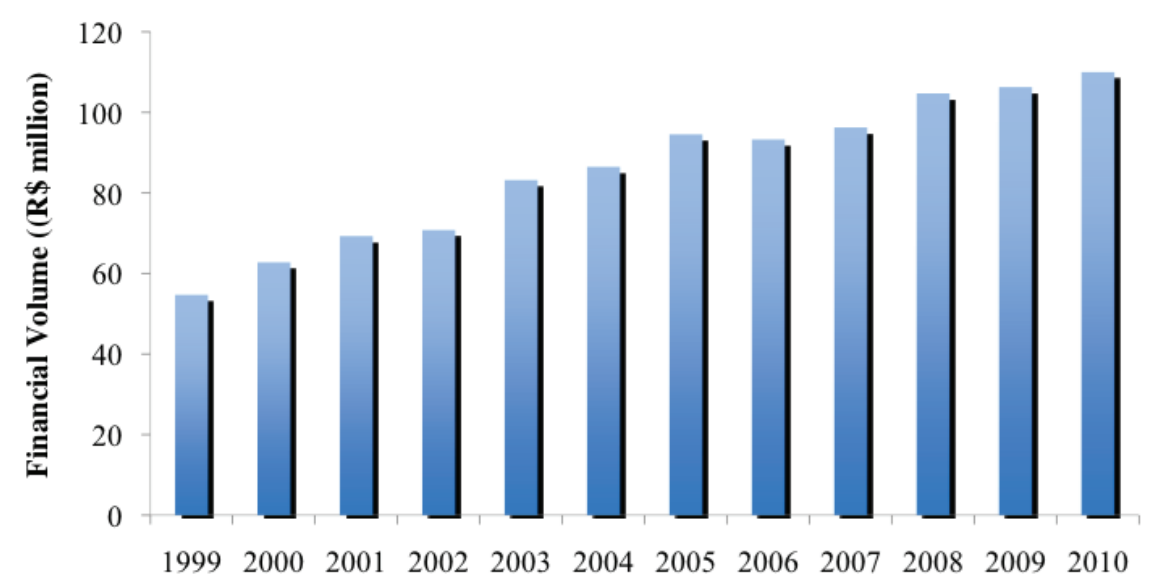

Figure 8. Financial volume declared by the traders of the Mercado Permanente de Flores e Plantas Ornamentais of Ceasa/Campinas (1999-2010).

In 2010, the financial volume declared by traders active in the market of CEASA/Campinas, excluding the sale of accessories, was R\$ 110 million (Figure 8). This value corresponds to $44.2 \%$ of the total sales of Veiling Holambra in the same year (Figure 6). The mean annual growth of the values traded (1999-2010) of Veiling Holambra (13.96\%) was $99.43 \%$ greater than that registered by CEASA/ Campinas, which was 7\%.

\section{CEAGESP-ETSP}

This market under federal management has the particular feature of not being a permanent market; the goods that are not sold must be removed from the locale after the market closes. This occurs because soon after the FOP market, the vegetable market begins. Thus, the trade figures of this trading center may not be compared to those of the other markets because the same goods may return several times to the location. Nevertheless, these values are shown so that the development of this market may be analyzed (TSUBOI and TSURUSHIMA, 2009).

Analysis of Figure 9 leads to the conclusion that the financial value of the entry of goods grew up to 2008, and that 2007 was the year of greatest growth, 124.4\%. However, most of this increase is due to expansion of the number of the items included in the list of products under study.

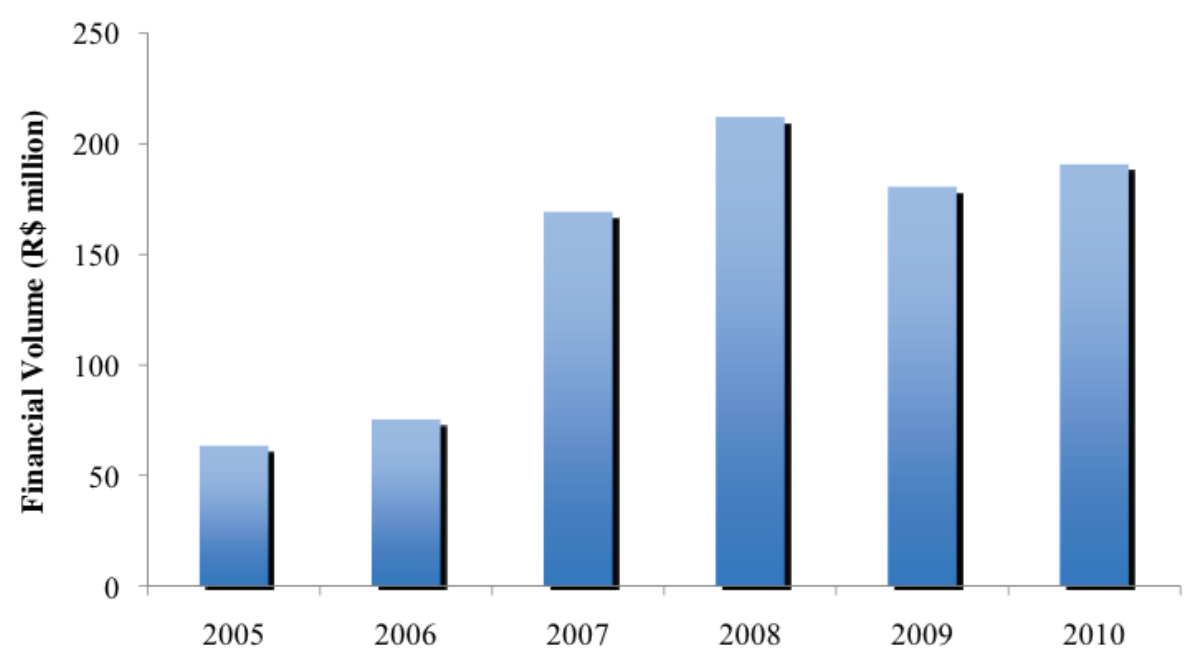

Figure 9. Financial volume declared in relation to the entry of flowers and ornamental plants in CEAGESP-ETSP (2005-2010). 
In analysis of Figure 10, the variation in growth of the main wholesale markets of FOP in Brazil may be seen - in the period 2005-2010, mean annual growth of Veiling Holambra was $12.9 \%$; CEASA/Campinas, $3.1 \%$; and CEAGESPETSP, $31.8 \%$ (considering only the declared values of entry of goods, not reflecting the real values traded).

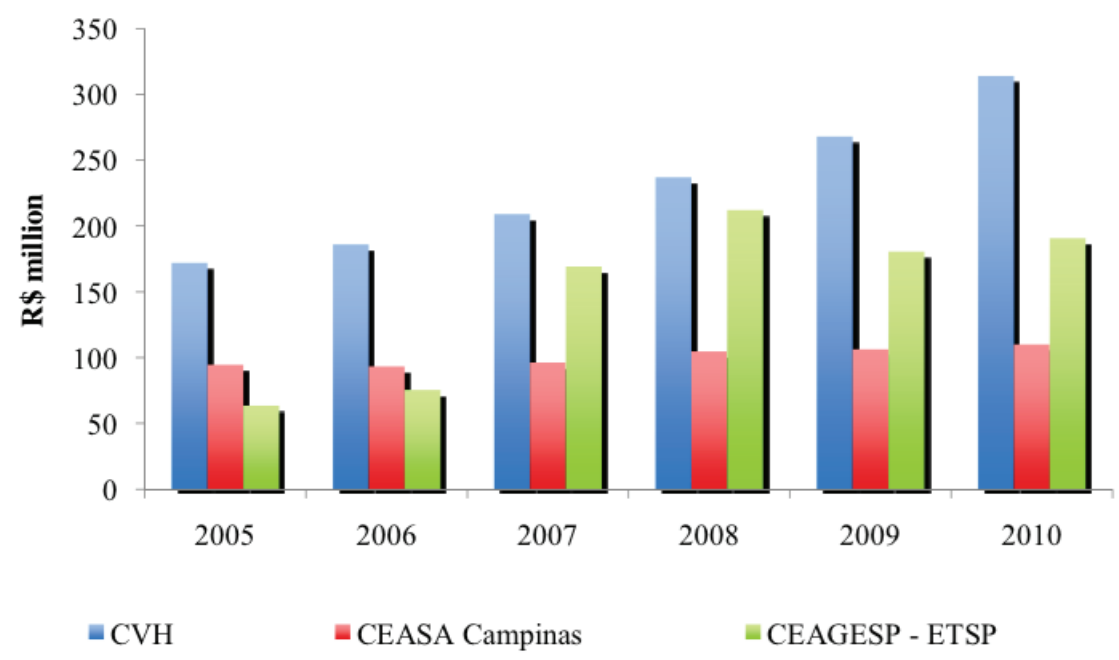

Figure 10. Volume traded* of flowers and ornamental plants by the trade centers in the period 2005-2010 (* the values of CEAGESP-ETSP refer only to the entry of goods and thus do not represent the real volume traded in the trading center)

Source: $\operatorname{CEAGESP}^{(7)}$

Nevertheless, the growth of $31.8 \%$ shown by CEAGESP-ETSP should be reconsidered since most of this increase is due to expansion of the data collected and not exclusively to the increase in product entry in the trading center. This was also the case in 2007, when growth in relation to 2006 was $124 \%$ (Figure 10).

Thus, considering only the period 2007-2010, Veiling Holambra is the market that shows greatest annual growth (14,5\%), followed by CEASA/Campinas (4.6\%), and CEAGESP-ETSP (5.4\%), confirming the expressiveness of Veiling Holambra in the Brazilian FOP market.

\section{Other markets}

In addition to the large scale markets discussed above, there are numerous other markets of regional and local importance. Among them, the markets of the Cooperativa Agrícola Flores de São Paulo - SP-Flores (located in Mogi das Cruzes, SP) and the market of the Companhia de Abastecimento e Distribuição do Estado da Guanabara (CADEG) stand out. The data on trade in these markets are even more limited than those made available by the large scale markets.

The SP-Flores was funded in July 2000 by the producers of AFLORD (Associação dos Floricultores da Região da Via Dutra). The SP-Flores has a great assortment of orchids, thus constituting an interesting market for those seeking less conventional goods. In 2007 there were around 73 members of the cooperative, 68 suppliers, and 441 buyers. Growth in the cooperative may be accompanied by the total sales - RS 3.67 million in 2003 compared to approximately $\mathrm{R} \$ 4.52$ million in 2007 (TSUBOI and TSURUSHIMA, 2009).

The CADEG is the main wholesale trade market of FOP in the state of Rio de Janeiro. Inaugurated in Janeiro 1962, the CADEG consists of 420 shops, including restaurants and shops of decorating items, fruits and vegetables, beverages, and FOP (TSUBOI and TSURUSHIMA, 2009). In addition to these shops, the FOP trade also occurs in a storehouse where producers and wholesalers have a flower trade fair. This flower trade fair receives from decorators and floriculture shop owners to individual consumers (SERVIÇO BRASILEIRO DE APOIO ÀS MICROS E PEQUENAS EMPRESAS - SEBRAE, 2003).

\section{CONCLUSIONS}

The wholesale market of flowers and ornamental plants in Brazil, which is concentrated in the state of São Paulo, is basically made up of the markets of Veiling Holambra, CEASA/Campinas, CEAGESP-ETSP, and Cooperflora/ Floranet. These markets, which show a positive history of growth, reflecting floriculture development in Brazil, have transactions of more than R $\$ 732$ million/year, and of this amount, $48.77 \%$ ( $\mathrm{R} \$ 357$ million), is through Veiling Holambra. 


\section{REFERENCES}

ARNALDI, C.R. Análise da eficiência de dois sistemas de distribuição de rosas no Estado de São Paulo. 2006. 112p. Dissertação (Mestrado em Agronomia) - Faculdade de Ciências Agronômicas da Unesp - Campus de Botucatu. 2006.

CASTRO, C.E.F. Cadeia produtiva de flores e plantas ornamentais. Revista Brasileira de Horticultura Ornamental, Campinas, v.4, n.1/2, p.1-46, 1998.

CEAGESP. Comercialização no ETSP é recorde em 31 anos. Available at: $<$ http://www.ceagesp.gov.br/ comunicacao/arquivo/2012/janeiro/260112/view?portal status_message $=\% 28-3 \% 2 \mathrm{C} \% 20 \% 27$ Temporary $\% 20$ failure $\% 20 \mathrm{in} \% 20$ name $\% 20$ resolution $\% 27 \% 29>$. Accessed on 21 Apr. 2012.

CEASA CAMPINAS. Maior mercado permanente da América Latina. Available at: $<\underline{\mathrm{http}}: / / \mathrm{www}$. CEASAcampinas.com.br/novo/Inst_Flores.asp $>$. Accessed on: 20 Apr. 2012.

COUGHLAN, A. T. ANDERSON, E.STERN, L. W. , EL ANSARI.A. I. Canais de marketing e distribuição. 6. ed. Porto Alegre: Bookman, 2002. 461 p
FLORANET. A empresa. Available at: <http://www. floranet.com.br/apresentacao.html>. Accessed on: 10 Jan. 2012

VEILING HOLAMBRA. Vantagens. Available at: $<\underline{\text { http: } / /}$ www.veiling.com.br/>. Accessed on 15 Feb. 2011.

JUNQUEIRA, A.H.; PEETZ, M.S. Mercado interno para os produtos da floricultura brasileira: características, tendências e importância socioeconômica recente. Revista Brasileira de Horticultura Ornamental, Campinas, v.14, n. 1, p.37-52, 2008.

SERVIÇO BRASILEIRO DE APOIO ÀS MICROS E PEQUENAS EMPRESAS. Diagnóstico da cadeia produtiva de flores e plantas ornamentais do Rio de Janeiro, 2003c. Available at: <http://201.2.114.147/bds/ BDS.nsf/8104AA054E31F117832572290065B9F4/\$File/ NT000B5F32.pdf>. Accessed on: 20 Mar. 2012.

TSUBOI, N.; TSURUSHIMA, H. Introdução à história da indústria de flores e plantas ornamentais no Brasil. Lip Gráfica, São Paulo, 2009. 276p.

VIZZOTO, F. E-commerce in the brazilian flower sector: caracterization, analysis and trends. 2011.57 p. Monografia (Management Studies) - Universidade de Wageningen, Wageningen, Holanda, 2011. 
